\title{
The role of parliament under ministerial government
}

\author{
Indriði H. Indriðason, Professor in political science, University of \\ California - Riverside \\ Gunnar Helgi Kristinsson, Professor in political science, University of \\ Iceland
}

\begin{abstract}
The present paper is concerned with the preconditions for ministerial government in Iceland and the role of parliament in sustaining it. Ministerial government is a form of coalition governance where the division of portfolios between parties functions as the basic mechanism of managing coalitions. Ministers are policy dictators in the sense that they control their ministries without interference from their coalition partners. Ministerial government is considered a weak form of coalition governance in the literature on account of its susceptibility to principal-agent problems, i.e., the temptation of ministers to adopt policies which are beneficial to their own party, or themselves, even if they are harmful to the coalition as a whole.

We argue that ministerial government was the guiding principle of coalition governance in Iceland prior to the crash of 2008. We demonstrate that given a number of conditions, ministerial government can in fact function effectively in the sense of providing the necessary minimum of inter-coalition checks. Instead of the cabinet providing oversight, however, the parties and committees in parliament play a key role in controlling policy drift. For a number of reasons, the financial crash in Iceland undermined some of the features on which ministerial government rested and coalition co-ordination after the crash has diverged significantly from the preceding period. It is too
\end{abstract}

Icelandic Review of Politics and Administration. Vol. 14, Issue 1. Special issue on power and democracy in Iceland (149-166) (C) 2018 Contact: Indriði H. Indriðason, indridi.indridason@ucr.edu

Article first published online May $31^{\text {st }} 2018$ on http://www.irpa.is

Publisher: Institute of Public Administration and Politics, Gimli, Sæmundargötu 1, 101 Reykjavík, Iceland

Stjórnmál \& stjórnsýsla. 1. tbl. 14. árg. 2018. Sérhefti um vald og lýđræđi á Íslandi (149-166) Fræđigreinar

(C) 2018 Tengiliður: Indriði H. Indriðason, indridi.indridason@ucr.edu

Vefbirting 31. maí 2018 - Birtist á vefnum http://www.irpa.is

Útgefandi: Stofnun stjórnsýslufræđa og stjórnmála, Gimli, Sæmundargötu 1, 101 Reykjavík

DOI: https://doi.org/10.13177/irpa.a.2018.14.1.7

This work is licensed under a Creative Commons Attribution 3.0 License. 
early, however, to tell whether these represent a permanent shift in coalition management in Iceland.

Keywords: Ministerial government; coalition management; bill amendment; Iceland.

\section{Introduction}

Ministerial government has come under increasing scrutiny in Iceland after the economic collapse of 2008 and the nature of ministerial accountability as well as the complexities of coalition management have received greater attention than before. This may partly be the result of increasingly difficult conditions for coalition governance as distrust of politicians and a more fragmented party system have to some extent undermined the foundations on which ministerial government rested. Our task is to delve into what the conditions for effective ministerial government might be and how they were influenced by the crash.

In an influential contribution to the literature on coalition governance, Laver and Shepsle (1994) argued that the main method for dealing with co-ordination problems in coalition governance was ministerial government. According to them, the initial agreement on portfolio allocations within a coalition is the key to its subsequent actions and policies. The "effective policy of any government", Laver and Shepsle $(1994,8)$ maintain, "depends upon the allocation of cabinet portfolios between politicians". Coalition policies reflect the partisan composition of the cabinet (rather than the influence of the bureaucracy or legislature) and the allocation of portfolios between parties (rather than the influence of the prime minister or the cabinet collectively) but on the whole the allocation of portfolios within the parties makes no difference. Thus "portfolio allocation does make a difference between, but not within, parties" (p. 10), at least so long as parties aren't too heterogeneous.

While ministerial government may be an efficient method of bargaining by reducing transaction costs, there are problems concerning its ability to deal with principal agent problems arising between party ministers and broader cabinet interests. In reality, ministers are usually not dictators within their portfolios and coalitions do attempt to make compromises across different issue areas (Dunleavy \& Bastow 2001).

Laver and Shepsle's insight that individual parties or ministers will have an incentive to renege on coalition-wide compromise has, nevertheless, guided much of the subsequent work on coalition governance. The idea of 'keeping tabs on partners', according to which the coalition facilitates oversight of coalition parties by their partners (Thies 2001) is, e.g. offered as a solution to the commitment problem and aims at protecting the coalition's negotiated agreement. Martin and Vanberg (2011), similarly, refer to parliaments as 'policing institutions' that allow coalition partners to monitor and modify legislative proposals made by ministers.

Several mechanisms have come under scrutiny as potential safeguards against ministerial shirking. This includes the coalition agreement which is negotiated before the coalition 
comes into power and is generally considered binding on coalition partners (e.g., Müller \& Strøm 2000; Moury 2013). Indridason and Kristinsson (2013) show that coalition agreements are employed by cabinets that are less likely to be cohesive and Bäck et al. (2016) show that they are in fact an effective mechanism of coalition management in the case of multi-member coalitions with common-pool resource problems. Cabinet controls of ministerial autonomy constitute another set of mechanisms which include the use of ministerial hierarchy - in particular Prime Ministerial power - and cabinet committees which may curb the independence of ministers substantially (Indridason \& Kristinsson 2015; Bowler et al. 2016). Watchdog mechanisms where coalition partners get to check ministry policies through Junior Ministers or parliamentary committee chairs can also function as important mechanisms of coordination in coalition governance (Thies 2001; Martin \& Vanberg 2011; Carroll \& Cox 2012).

On the strength of the theoretical and empirical criticism directed at the model of ministerial government, we might expect such systems to be rare and unstable. Nonetheless, we maintain that two main conditions may facilitate such a governance mode. One is that small ideological differences between parties are likely to reduce agency cost in coalition governance by reducing the temptation of ministers (or their parties) to shirk on the coalition deal. Laver and Shepsle's model - at least according to the initial formulation - makes no assumptions concerning the role of ideology in coalition governance. ${ }^{1}$ In that model, coalition governance is simply a log-rolling procedure, where influence is traded across issue areas rather than within them. If ministerial government is to function effectively, however, it would seem an obvious advantage if the policy preferences of a minister's party are similar to those of his or her partners. This will reduce agency costs within the coalition. Even in cases where parties are influenced more by office seeking than policy concerns, e.g. on account of a large emphasis on patronage and material rewards, small ideological distance is likely to minimize political frictions within the coalition and facilitate peaceful (in this case departmentalized) sharing of the spoils.

The second facilitating factor is a powerful parliament which can enforce the incomplete contract implicit in the coalition bargain on an ad hoc basis. By this we do not mean the use of watchdog chairs of parliamentary committees, which are more properly seen as part of the original coalition bargain than an attempt to bypass the need for such a deal, which ministerial government is all about. Instead, we assume that the coalition party groups in parliament develop coalition policy on an on-going basis, not necessarily in accordance with any pre-conceived plan. This means that parliamentary committees must be relatively free to amend government proposals at their discretion. The coalition deal is not simply enforced by the committees; it is partly made there. For such a mechanism to function effectively, however, a solid parliamentary majority and a high degree of party cohesion are required. Numerically weak majorities and fragmented parties risk being exposed to blackmail by small groups of MPs; they may often be forced to make major changes to ministerial policy. Hence, ministerial government is likely to function effectively with majority coalitions where party discipline is relatively high. ${ }^{2}$ 


\section{Ministerial government in Iceland}

Ministerial government is deeply embedded in Icelandic jurisprudence and political practice. Ministers are chief executives in their respective divisions of the administrative system and they are neither obliged to take orders from the Prime Minister nor the Cabinet according to law. The legal situation in this case corresponds fairly well with political reality. Ministers control their ministries. The main features of ministerial government in Iceland include short coalition agreements, weak hierarchy among ministers, little collective cabinet control of ministers, and little use of watchdog mechanisms.

Short coalition agreements. Coalition agreements, dealing exclusively with policy issues, are regularly issued by Icelandic coalitions. While coalition formation is often a drawnout process, the coalition agreements themselves are short and usually written by the party leaders, their deputy leaders, and, in recent years, their personal assistants. A simple method of evaluating the extensiveness of the coalition agreements is to count the number of words they contain. While verbosity may vary from one political context to another, the number of words has been shown to be a significant predictor of behavior (Back et al. 2017). Table 1 indicates that compared to other parliamentary systems coalition agreements in Iceland tend to be relatively short.

Table 1. Coalition agreements 1980-2007: Mean number of words

\begin{tabular}{lcc}
\hline State & Mean number of words & N \\
\hline Netherlands & 22067 & 6 \\
Norway & 20781 & 4 \\
Portugal & 18380 & 2 \\
Belgium & 17306 & 8 \\
Ireland & 9913 & 6 \\
Germany & 8069 & 7 \\
Denmark & 4296 & 4 \\
Sweden & 3300 & 2 \\
Iceland & 2550 & 9 \\
Finland & 2437 & 8 \\
France & 1976 & 5 \\
\hline
\end{tabular}

Sources: Müller \& Strøm (2000), Indriði H. Indriðason (2005) and Stefnuyfirlýsing ríkisstjórnarinnar 2007.

Iceland is among the states where coalition agreements are shortest. The only countries where coalition agreements are shorter, according to table 1, are semi-presidential systems that may not be fully comparable to parliamentary regimes. The mean length of coalition agreements in the 11 states was 9702 words. The longest agreement in Iceland in this period was 4505 words, less than half the average length. Coalition agreements in Iceland, however, were normally only about one quarter of the average in this sample. 


\section{STJÓRNMÁL \& \\ STJÓRNSÝSLA}

The post-crash period, however, has seen substantial lengthening of coalition agreements to 6496 words on average in the case of majority coalitions.

Weak ministerial hierarchy. Ministerial positions may vary in importance. Above all, the Prime Minister may be highly influential in some cabinets, and in some cases other ministers such as the minister of finance and the portfolios controlled by the leaders of other coalition parties also have outsized influence. In the Icelandic case, however, the PM has very limited formal powers and even less informal ones. According to the letter of the constitution, the PM appoints ministers, decides their tasks, and fires them as the case may be. In practice, each coalition party selects its own ministers and even the PM needs the approval of his or her parliamentary group before deciding on the list of appointees from his or her party. There are no known examples of coalition partners interfering with each other's choice of ministers. And in the rare cases where there are calls for the resignation of an individual minister, the PM typically delegates the issue entirely to the respective party leader or parliamentary group.

International comparisons show that the Icelandic PM is less influential than most of his or her colleagues. According to O'Malley's (2007) expert survey, the Icelandic PM is the least influential in a group of 22 parliamentary democracies while according to Druckman and Warwick's (2005) estimates, the Icelandic PM ranks the third lowest in a group of 11 states. ${ }^{3}$ While the limited coordinating ability stemming from a weak PM may in some cases be offset by strong cabinet committees or collective leadership, the use of cabinet committees in Iceland dates only back to the 1990s and they have remained fairly few in numbers. It is also noteworthy that in Warwick and Druckman's dataset the second most influential minister - in Iceland the minister of finance - ties as the second least influential "second" minister.

Little collective cabinet control. The division of labor between ministers and the cabinet in Iceland is broadly based on ministerial autonomy in all administrative matters and votes are never cast in the cabinet. Thus, the Icelandic cabinet is very different from the Swedish one, which can issue directives to the administration - which individual ministers cannot - and formally takes tens of thousands of decisions every year. Most parliamentary systems define a set of issues where collective cabinet approval is needed (e.g. Eriksen 2003; Andeweg \& Bakema 1994). This may include directives, white papers, major policy declarations, public appointments, committee appointments etc. In the Icelandic case the ministers are obliged to inform the cabinet concerning "important government business" (as the Constitution puts it) but the cabinet has no power to intervene. Only with regard to government bills does the cabinet have veto power, but in effect this is limited by a number of factors. Usually the agenda of cabinet meetings - at least prior to the revision of the Ministry Act in 2011 - was only made available the night before a cabinet meeting and relevant documents might not even be distributed until the morning of the meeting. Although agenda items are usually postponed upon request, this seriously limits the ability of cabinet ministers and their assistants to scrutinize the work of their colleagues (Samhent stjórnsýsla 2010, 38). 
Little use of watchdog mechanisms. One of the main characteristics of ministerial government is the absence of any type of watchdog mechanisms except the occasional use of watchdog chairs in parliamentary committees. There exist no Junior Minister positions in Iceland. Although ministers have access to political assistance in a number of ways, this is exclusively used at the minister's own discretion. In most cases ministerial assistants are used to assist with public relations and party networking (Kristinsson 2016). While the idea of introducing Junior Minister has been aired on rare occasions, it is safe to say that the idea of appointing a Junior Minister from another party is entirely foreign to Icelandic politicians.

Committee chairs, prior to the crash, were generally thought of as the Minister's closest collaborators in parliament. While they might in some cases exert a certain degree of influence on the Minister - since they were in control of the committee agenda - the use of watchdog chairs was not common. In $2003-2009,79 \%$ of committee chairs were the respective ministers' co-partisans.

Why the Icelandic political parties adopted ministerial government over other forms of coalition management remains an important question, although we deal with it only tentatively in the present paper. Material benefits have traditionally been an important part of the payoffs of coalition membership in Iceland. During the inter-war period, the parties developed a strong patronage orientation, which aimed at satisfying important constituency and sectoral interests (Indriðason 2005; Kristinsson 1996). Being excluded from power thus meant being starved of the material benefits that government office provided. Hence, there was a strong office-seeking element in the major parties, not only among the party elites but reaching down to the network of party supporters on the ground, who stood to benefit from access to power.

By making the division of portfolios the focal point of coalition governance the parties introduced a relatively simple principle for dividing the spoils. Each party controlled its portfolios without much outside interference. Only where major interests were at stake did the parties establish more elaborate mechanisms for sharing, such as in the financial system and foreign trade, where inter-party committees or boards and party quotas in the divisions of administrative positions were common. The main players in this system were the Independence Party, representing private enterprise and the middle class, and the Progressive Party, representing farmers, the co-operative movement, and sparsely populated regions. Until 2008, every coalition, since the modern party system was molded around 1930, contained one or both of these parties. The occasional appearance of other parties in government occurred when one or more of the left wing parties managed to gain access. The left in Iceland, however, was much weaker and fragmented than in the Scandinavian states.

Interviews with political leaders indicate that the IP and PP remain broadly satisfied with the ministerial form of government, which was practiced without serious challenges until the economic meltdown in 2008. Greater skepticism existed on the left. After the crash, criticism of the existing mode of coalition governance grew, especially when the Special Investigation Commission appointed by the Alpingi concluded that 
lack of inter-ministerial co-ordination was partly to blame for ineffective response to the impending threat of financial meltdown (SIC 2010). The new left-wing coalition which took over after the crash therefore was determined to introduce reforms not only of economic and social policies but also of the way politics was practiced in government and parliament.

Several aspects of politics in the period following the crash indicate that an attempt was made to abandon the practice of ministerial governance. In the first place, coalition agreements became much more detailed than before. The coalition agreement of Sigurðardóttir's majority coalition in 2009 was 6997 words or roughly 2.7 times the pre-2009 mean. While subsequent agreements have been shorter, they have been considerably longer than in the previous period, i.e. between 4 and 5.5 thousand words. The Ministry Act was revised in 2011 to strengthen coordination mechanisms at the cabinet and ministry level, including a new section on cabinet committees and, at least in the left-wing government of 2009-2013, the joint leadership of the two coalition parties was clearly more assertive vis-à-vis individual ministers than usually had been the case. The use of watchdog chairs increased substantially in the governments formed after the economic crisis although it bears noting that the comparison is complicated by the fact that Alpingi's committee system changed in 2011. Alpingi's committees used to largely mirror the ministerial portfolio jurisdictions but that was no longer true after the 2011 reform. Rather than hazarding a guess at which portfolio each committee matches best, we examine all government bills between the legislation sessions starting in 2003 and concluding in 2014 and ask whether the proposing minister and the chairman of the committee to which the bill was assigned came from the same party. ${ }^{4}$ Table 2 shows a very sharp decline in government bills that go through a committee chaired by an MP from the same party as the minister that introduced the legislation in parliament.

Table 2. Same party committee chairs 2003-2014: \% of parliamentary bills

\begin{tabular}{lccc}
\hline Government Coalition & Same Party Chairs & Mean Policy5 Distance & N \\
\hline IP-PP 2003-07 & $73.00 \%$ & 4.8 & 474 \\
IP-SDA 2007-09 & $93.00 \%$ & 9.4 & 196 \\
SDA-LG 2009-13 & $33.00 \%$ & 7.8 & 572 \\
PP-IP 2013-14 & $31.00 \%$ & 1.3 & 104 \\
Total & $55.00 \%$ & 6.7 & 1346 \\
\hline
\end{tabular}

In part the changes that took place reflected widespread discontent with party dominated politics as well as ministerial government. This was especially apparent on the left, among the Left-Greens, but the popular discontent affected all parties to some extent. Thus, party cohesion fell not only in the governing parties but also in the opposition (Kristinsson 2011). A significant aspect of the change which took place, and the attempt to move away from ministerial governance, was greater willingness to accept small coalition majorities or even minority governments. The left-wing government which took 
over in February 2009 was a minority government and even if it obtained a majority in the ensuing elections its majority had become shaky already by 2010 and it formally became a minority government again in 2012. Ministerial government, we maintain, requires strong majorities and cohesive parties in order for them to be able to deliver support for policies that are not easy to digest for all the coalition partners. The left-wing government which came into power was united more on a negative basis - against the IP and PP, which were widely blamed for the crash - and was forced to rely on more formal co-ordination mechanisms than earlier coalitions. Even so, the strain was formidable and after suffering a number of major political losses, the coalition eventually lost its majority and finished as a minority.

Our predictions concerning the impact of ideological distance in the period leading up to 2008 are therefore not expected to hold in the subsequent period. Eroding majorities and weaker party cohesion should lead to greater changes in government bills after the crash. Since ministers are more bound by the collective cabinet than in the preceding period, we should expect ideological distance to play a smaller role than before.

Above we have offered some evidence that appears consistent with Iceland having transitioned from a form of cabinet governance that can be characterized as a ministerial government to a form that places greater emphasis on coordination within the cabinet. We now turn to examining some additional implication of our thesis that focus on the changes in legislative politics that should accompany a decline in ministerial government. As the conditions that supported ministerial government gave way in the wake of the financial crisis, eroding majorities and less party cohesion generate conditions in which Alpingi amends government legislation to a greater extent than it did previously. That is, the less the government can rely on its party members to rubberstamp its legislation, the greater are the compromises it has to make. More importantly, the effect of ideological differences can be expected to change. Under ministerial government, there is little coordination within the cabinet and ministers are fairly autonomous when it comes to producing government bills. In such circumstances, Alpingi plays an important oversight role that serves to protect the (formal or informal) coalition agreement and maintain the coalition. Thus, when ideological differences within the coalition are large, the differences between the minister's bill and the preferred outcome of his or her coalition partner are larger. Subsequently, the more extensively the minister's bill is expected to be amended, the greater the ideological differences. In contrast, in the post-crisis period when there is less ministerial autonomy and greater coordination at the level of the cabinet, the extent to which government legislation is amended in the legislature is not expected to depend on ideological differences - that is, greater coordination within the cabinet at an earlier stage implies that the differences in the parties' preferences have already been addressed. In the next section we examine this hypothesis as well as additional factors believed to affect amendment rates using data on all government bills presented in Alpingi between 2003 and 2014. 


\section{STJÓRNMÁL \& \\ STJÓRNSÝSLA}

\section{Empirical analysis}

\subsection{Data and methods}

Our key independent variable is the degree to which government bills are amended. The amount of change is measured, as suggested by Pedrazzani and Zucchini (2013) as the number of words changed from the initial version of the bill presented to parliament to final legislation approved by parliament. Changes in the content of a bill from its introduction to adoption are measured by counting the number of words in the bill $(k)$, the number of words in the adopted legislation $(D)$, the number of deleted words in a bill $(m)$ and the number of new words in the adopted legislation $(n)$. The amount of change is calculated according to the formula. The theoretical range of the change coefficient, $x$, is from 0 to 100 , where 0 indicates identical documents and 100 means that the document is unrecognizable.

In the period under study, 2003-2014, a total of 1457 government bills, excluding budgetary bills, were introduced in the Alpingi. ${ }^{6}$ Their fate is reported in table 3. Budget related bills are not available in a format suitable for the present analysis but all 36 of them were, however, approved.

Table 3. Fate of government bills 2003-2014

\begin{tabular}{|c|c|c|}
\hline Fate & Number of Bills & $\%$ \\
\hline Not Approved & 353 & 24.8 \\
\hline Approved w/Amendments & 918 & 64.6 \\
\hline Approved w/o Amendments & 150 & 10.6 \\
\hline Total: & 1457 & 100.0 \\
\hline
\end{tabular}

About a quarter of all government bills fail to be adopted. In a comparative perspective, the proportion of government bills passed (i.e., $75.2 \%$ of introduced government bills) is not unusual. According to Bräuninger amd Debus $(2009,820)$, the corresponding figures for Belgium, France, Germany, and the United Kingdom are in the 68-95\% range. Legislative activism of the Icelandic Alpingi is better reflected in the amount of changes made to government bills than in the number of government bills blocked. Table 4 summarizes the total number of words in the legislative text and commentary in government bills according to the fate of the legislative proposal. Bills that pass without amendments $(10.6 \%$ of government bills) are primarily short bills of secondary importance - they average just over one thousand words. In contrast, bills that fail are on average close to ten thousand words and bills passing with amendments are close to six thousand words. Other evidence supports the interpretation that these bills are of secondary importance, including the number of speeches made in plenum during discussions and the number of comments received by the parliamentary committees, both of which are much lower than in the case of bills which pass with changes. 
Table 4. Total length of bills and explanatory notes

\begin{tabular}{lccc}
\hline Fate of Bill & Mean & N & Standard Deviation \\
\hline Not Approved & 9937 & 350 & 14608 \\
Approved w/Amendments & 5781 & 918 & 9937 \\
Approved w/o Amendments & 1160 & 150 & 2115 \\
\hline Total & 6318 & 1418 & 11098 \\
\hline
\end{tabular}

Considering that the great majority of approved legislation is adopted after the initial bill is amended it is clear that amendments are an important form of parliamentary activism in Alpingi. Figure 1 shows the average change coefficient for each session in our data set (additional summary statistics are provided in the appendix). The average change coefficient for adopted legislation is about $20 \%$. The average prior to the crash in 2008 is slightly lower (15\%) but still substantially higher than might be expected in a parliamentary system. After the crash the amount of amendments to government bills is higher (26\%) although the exceptionally high numbers for 2011-2012 account for a considerable part of the change. Higher rates of amendment can partly be accounted for by weak support for the government in parliament in 2010-2013. The return of a strong parliamentary majority in 2013 , however, seems not to have facilitated a return to pre-crisis figures. An average change of 21\% in the session of 2013-2014 is still considerably higher than anything seen prior to the crash.

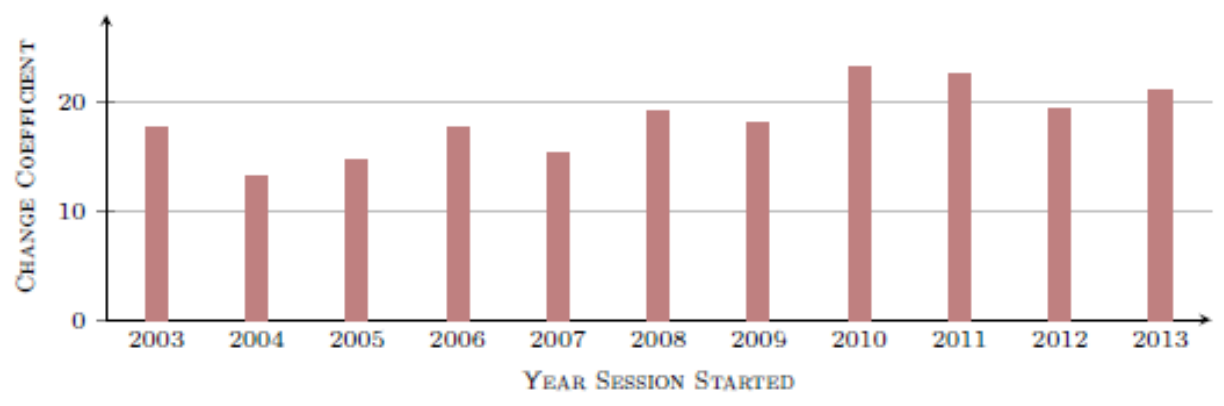

Figure 1. Degree of Bill Amendment: Change coefficient

Turning to our independent variable, the key question of interest is how intra-coalitional ideological differences shape legislation. We conducted an expert survey in which 26 experts (academics, journalists, and specialists in Alpingi) were asked about the ideological positions of key political actors in the issue area corresponding to each of the ministerial portfolios. Thus, within each portfolio, we have estimates of the ideological positions of each political party as well as the cabinet ministers occupying the portfolio. We consider two measures. The first measure, Ideological Distance: Coalition Parties, is simply the ideological distance between the coalition partners (all the coalitions were two-party coalitions). 
The second measure, Ideological Distance: Minister-Own Party, considers the difference in the issue positions of the minister and his own party — if the legislative committees have a role in providing ministers with oversight then more extensive amendments are expected when the minister is a poor representative of her party on the issue.

Committee chairs that share party affiliation with the minister in charge of the corresponding portfolio are expected to usher bills through the committee and to shield them from extensive revisions. In contrast, if the committee is chaired by a member of the coalition partner, the bill is less likely to become a law but if it does it is subjected to greater amendments. The variable Same Party Committee Chair is coded one when the portfolio minister and the committee chair are members of the same party.

Government MPs is the total number of government party MPs. An indicator variable for Minority Governments is also included to account for the possibility that minority governments face different challenges in passing legislation. While minority governments are rare in Iceland, there are two minority governments in the period under study. First, a caretaker cabinet of the Social Democratic Alliance and the Left-Green Movement was in office for few months ahead of the 2009 election. Second, after continuing in office as a majority government following the 2009 election, the SDA-LGM coalition lost its parliamentary majority in 2011 and governed as a minority coalition until 2013. Pedrazzani and Zucchini $(2013,687)$ suggest that more changes are made to minority government bills than others.

Stakeholder attention was measured through the Number of Comments on the legislative proposal submitted to Alpingi by various actors. We consider both the total number of comments received as well as the number of comments offered by specific groups of actors. In different parts of the analysis we report the results for the number of comments offered by interest groups and private sector actors. ${ }^{7}$

We include several control variables in our analysis. Legislation varies in complexity, which may affect the extent of amendment. Alpingi is ill-equipped with dealing with complex legislation - at least relative to the expertise that exists in the bureaucracy. While MPs may not lack the will to intervene in government legislation, they often lack expertise or access to information to effectively scrutinize the legislation. The lack of expertise may reduce how much a complex government bill is amended but it is also possible that Alpingi, in the face of complex issues, will opt not to act on the legislative proposal. ${ }^{8}$ When complex bills are passed, they are, however, amended less than relatively simple legislative proposals. The first measure of bill complexity is simply its length, Bill Length, measured in thousands of words. An explanatory note or a memorandum generally accompanies legislative proposals in Alpingi. Unlike the explanatory notes in, e.g., UK's House of Commons, that offer a simple explanation of the purpose and effect of the legislation - explanatory notes in Alpingi can contain an extensive discussion of the legislation context, providing both the rationale for its introduction and justification of its contents. The length of the explanatory note serves as another measure of the complexity of the legislation.

Legislative proposals expire at the end of a legislative session and must be reintro- 
duced in the following session if not adopted into law. With each legislative session lasting about eight or nine months, the cabinet and legislature face significant time pressures and legislation introduced late in the term is, other things equal, less likely to be adopted. Ministers may, however, face a dilemma when it comes to the timing of bill introduction. While a bill that is introduced early in a legislative session is more likely to be adopted, introducing bills early will also allow the committees ample time to amend it. To account for the effects of timing of introduction, the variable Days Remaining measures the number of months until the time that Alpingi normally concludes its business for the session, i.e., in June each year except in election years when the session ends at the end of April. ${ }^{9}$ An indicator variable for Election Year is also included to account for the fact that a shorter session may alter the dynamics of the legislative process — as, indeed, may the fact that elections are looming on the horizon.

Time can also work in favor of the opposition. The parliamentary majority is not checked by many veto points. While the president may refuse to countersign legislation, which triggers a referendum on the legislation, this has only been used three times since the establishment of the republic in 1944 and is, in any case, not a mechanism controlled by the opposition. The main tool of the opposition to influence legislation — in the face of a united government majority - is the filibuster.

Technically the government can end filibusters, but a tacit agreement exists among the parties not to use such measures. Bills that are not adopted in a given parliamentary session have to be introduced anew in the following session if they are not abandoned. Towards the end of the parliamentary session the government sometimes gets into a time crunch with its legislative program and has to negotiate with the opposition on the order of priorities. This provides an opportunity for the opposition to influence which bills are passed and potentially their content as well. The opposition is likely to use such pressure to thwart bills that address salient issues while the government is likely to prioritize those bills. Salient bills attracting a lot of attention during parliamentary debates are likely to be seen as a test of the government's governing capacity and are hence more likely to be prioritized by the government and more likely to be passed. Barring a filibuster, the government is typically in a position to pass its legislation as party discipline is high in the Icelandic parties and comparable to the Scandinavian countries (Kristinsson 2011).

Legislation that is considered highly salient in government-opposition terms is expected to be more likely to be adopted but not necessarily amended less. Measuring the salience of a particular legislative proposal is challenging but we consider speeches made in plenum as a proxy. First, we consider the Number of Speakers that offered their views on the legislation by speaking to the chamber. Second, allowing for the possibility that some MPs speak multiple times, we count the Number of Speeches made in the chamber.

We use OLS regression models to estimate the effect of the covariates on the extent to which a bill is amended. ${ }^{10}$ As our expectation is that Icelandic cabinets functioned as ministerial cabinets until 2008 but took a more collegial from after the economic crisis, we present two sets of models; one focusing on the parliaments prior to 2008 and one for the ones after $2008 .^{11}$ 


\section{STJÓRNMÁL \& \\ STJÓRNSÝSLA}

\subsection{Results}

The results of the analysis of how extensively government legislation is amended are presented in table 5 and are largely in line with expectations. Prior to the crash, greater ideological distance between the coalition parties on a given policy issue was associated with more amendment as expected if the coalition parties use the legislature to enforce the coalition agreement, i.e., a minister's bill is more likely to deviate from the coalition compromise the further apart the parties are ideologically. A standard deviation change in the value of issue distance corresponds to a three percentage points more amendments - moving from the minimum to maximum policy difference amounts to an eleven percentage points change. We also find that an increase in the policy distance between a minister and his own party is associated with less extensive amendments, which is a somewhat unexpected finding. A priori, if the coalition uses Alpingi to enforce the coalition agreement one would expect more legislative amendments when the minister is ideologically distant from her own party. There are two possible reasons, related to selection effects, for why this might not be the case. First, parties may be unlikely to appoint ideological outliers to portfolios they consider highly salient. Thus, ideological outliers may be most likely to be found in portfolios that the party cares less about and, thus, involves legislation the party may not be too bothered about amending. Second, ministers that are ideologically distant from their own parties may be closer to the ideological preferences of their coalition partners. They may be more likely to propose legislation that is closer to the coalition compromise and, thus, it is less likely to require extensive amending. After 2008, these patterns disappear, and ideological differences do not have statistically significant effect on amendment activity. ${ }^{12}$

The party identity of the committee chair was hypothesized to influence the extent to which bills are amended. In particular, bills are expected to be amended more when the committee chair and the minister in the relevant portfolio are not members of the same party. The results prior to the crisis suggest that this might be the case; the coefficient for watchdog or shadow chairs is positive but is not statistically significant at the conventional levels. After the crisis, the effect of shadow chairs flips around (but, again, is not statistically significant).

Our measures of stakeholder interest focused on the number of submitted comments on a particular piece of legislation by external actors. More contentious and salient pieces of legislation are more likely to receive comments and, as expected, bills that receive more comments are amended more extensively. Taking a closer look at where the comments come from it becomes apparent that before the crisis comments from the private sector were most strongly associated with changes in the bill. ${ }^{13}$ Comments from private sector actors, however, have a smaller and statistically insignificant effect after the crisis while comments from interest groups have a bigger, and now statistically significant, effect after the crisis.

Most of our control variables did not have a statistically significant effect on the amendment rate. The exceptions to that were the two variables that had to do with timing when examining amendment activity prior to the economic crisis. Prior to the crisis, 
bills introduced early in the session were amended more extensively which was also true of bills introduced in sessions leading up to an election year.

Table 5. Bill amendment

\begin{tabular}{|c|c|c|c|c|}
\hline & \multicolumn{2}{|c|}{ Pre-Collapse } & \multicolumn{2}{|c|}{ Post-Collapse } \\
\hline & (1) & (2) & (3) & (4) \\
\hline Ideological Distance & $\begin{array}{r}0.50 * * \\
(0.2)\end{array}$ & $\begin{array}{r}0.50^{* * *} \\
(0.2)\end{array}$ & $\begin{array}{r}-0.18 \\
(0.2)\end{array}$ & $\begin{array}{r}-0.28 \\
(0.2)\end{array}$ \\
\hline Dist. Minister-Own Party & $\begin{array}{r}-1.39 * \\
(0.7)\end{array}$ & $\begin{array}{r}-1.52^{* *} \\
(0.7)\end{array}$ & $\begin{array}{l}0.18 \\
(0.4)\end{array}$ & $\begin{array}{r}-0.054 \\
(0.4)\end{array}$ \\
\hline Shadow Chair & $\begin{array}{l}1.58 \\
(2.6)\end{array}$ & $\begin{array}{l}2.55 \\
(2.6)\end{array}$ & $\begin{array}{r}-3.11 \\
(2.9)\end{array}$ & $\begin{array}{r}-4.91 \\
(3.1)\end{array}$ \\
\hline Government MPs & $\begin{array}{r}-0.22 \\
(0.3)\end{array}$ & $\begin{array}{r}-0.0049 \\
(0.3)\end{array}$ & $\begin{array}{r}-0.50 \\
(0.6)\end{array}$ & $\begin{array}{r}-1.09 \\
(0.8)\end{array}$ \\
\hline Minority Gov't & $\begin{array}{r}-2.15 \\
(4.5)\end{array}$ & $\begin{array}{r}-0.69 \\
(4.5)\end{array}$ & $\begin{array}{l}0.65 \\
(8.5)\end{array}$ & $\begin{array}{l}3.50 \\
(8.7)\end{array}$ \\
\hline Bill Length (words) & & $\begin{array}{r}-0.63 \\
(0.5)\end{array}$ & & $\begin{array}{r}-0.24 \\
(0.6)\end{array}$ \\
\hline Explanatory Note Length (words) & & $\begin{array}{r}-0.070 \\
(0.2)\end{array}$ & & $\begin{array}{r}-0.16 \\
(0.2)\end{array}$ \\
\hline Days Remaining & & $\begin{array}{r}0.038^{* *} \\
(0.02)\end{array}$ & & $\begin{array}{l}0.027 \\
(0.02)\end{array}$ \\
\hline Election Year & & $\begin{array}{r}5.22^{* *} \\
(2.6)\end{array}$ & & $\begin{array}{r}-3.40 \\
(4.3)\end{array}$ \\
\hline No. $\sim$ Speeches & & $\begin{array}{l}0.013 \\
(0.02)\end{array}$ & & $\begin{array}{r}-0.0074 \\
(0.006)\end{array}$ \\
\hline Comments - Total & $\begin{array}{r}0.23^{* * *} \\
(0.09)\end{array}$ & & $\begin{array}{r}0.54^{* * *} \\
(0.1)\end{array}$ & \\
\hline Comments - Interest Groups & & $\begin{array}{l}0.28 \\
(0.3)\end{array}$ & & $\begin{array}{r}1.99 * * * \\
(0.4)\end{array}$ \\
\hline Comments - Private Sector & & $\begin{array}{r}1.67^{* * *} \\
(0.6)\end{array}$ & & $\begin{array}{l}0.96 \\
(0.8)\end{array}$ \\
\hline Constant & $\begin{array}{c}20.4^{*} \\
(11.3)\end{array}$ & $\begin{array}{r}6.14 \\
(11.7)\end{array}$ & $\begin{array}{r}33.7 \\
(22.0)\end{array}$ & $\begin{array}{l}52.5^{*} \\
(27.7)\end{array}$ \\
\hline Observations & 549 & 549 & 341 & 341 \\
\hline R2 & 0.027 & 0.062 & 0.080 & 0.14 \\
\hline
\end{tabular}

Standard errors in parentheses. ${ }^{*} p<0.10,{ }^{* *} p<0.05,{ }^{* * *} p<0.01$.

\section{Conclusion}

Despite widespread scepticism about ministerial government it appears it can function effectively under certain conditions. Prior to the economic crash of 2008, Iceland had a strong element of ministerial government, including short coalition agreements, weak ministerial hierarchy, and little use of collective cabinet control or watchdog mecha- 
nisms. Each party was left relatively free to control its issue area although with some exceptions. In the case of legislation, the Alpingi played an unusually active role in processing government bills where minimum winning coalitions of two or three parties simplified the process of negotiation. Strong party cohesion also contributed to coalition management by strengthening the credibility of party commitment. Our analysis indicates that small ideological distance between ministers and their coalition partners contributed to the safer passage of bills and smaller amendments in parliament. Part of making this system work involved allowing lobbyists of various kinds relatively unfettered access to Alpingi so that interests associated with the different coalition partners could have a say in how government bills developed.

After the crash several features of coalition governance changed considerably. Although Alpingi remains an important arena for lobbyism, the development of more collective cabinet mechanisms has weakened ministerial control to some extent. More extensive coalition agreements, greater attention to hierarchy in government and greater use of watchdog chairs seem to have undermined ministerial autonomy to some extent.

However, several features of the old system remain in force, including the centrality of the Alpingi as an arena for stakeholder interests and the legal framework is still to a large extent geared towards ministerial government. In fact, the issue of ministerial autonomy and collective control has to a certain extent become a contested issue. While the IP and PP seem to remain happy with ministerial government, some of the other political forces are more sceptical. Thus, strong interpretations of ministerial autonomy may have played a role in the downfall of the three-way coalition of the IP and two of the new political forces in 2017. One of them, Bright Future, refused to take responsibility for the actions of IP ministers and left the coalition - an unprecedented occurrence in Icelandic politics.

\section{Notes}

1 In Laver and Shepsle's model, ideology influences which coalition forms but it is assumed not to have other implications for coalition governance, e.g., that larger ideological differences may make the coalition more difficult to maintain.

2 Ministerial government is more commonly associated with weak parliaments that lack the ability to curtail the powers of the cabinet. Our claim here is that ministerial government is also possible in the presence of a strong parliament, provided that the cabinet parties are able to maintain disciplined parties.

3 According to Strøm et al. (2003, 183-189) measure of the prime minister's institutional power, Iceland scores 3 (on a seven-point scale), with ten of the seventeen countries scoring higher on their scale.

4 A potential limitation of this comparison is that the ministers may present different numbers of government bills. However, one may also argue that the focus on government bills is of greater substantive interest, i.e., 'shadow chairs' are only important to the extent that they actually deal with legislation originating from a minister of a different party.

5 On the measurement of policy distance, see below.

6 The analysis is confined to government bills.

7 The comments were coded based on whether they were submitted by parliamentary committees, political actors, ministries, public institutions, local governments, occupational groups, interest 
groups, research institutions, the private sector, organizations and clubs, and individuals. Comments by other actors, e.g., government departments, government agencies, and public organizations, were also considered but did not appear to have a systematic effect on the degree of amendment.

8 One potential issue here is that bills expire at the end of each session. Thus, Alpingi may allow bills to "fail" in order for them to be reintroduced in the following session to continue work on the bill.

9 Alpingi's sessions run from October 1 each year until the end of the September the following year. Normally the last meetings of Alpingi occur around mid-June although in a few instances Alpingi reconvenes in the same session in late fall. In addition, there are short summer sessions in election years following the election but typically Alpingi does not conduct much business during the summer sessions. We exclude bills proposed during reconvened and summer sessions of Alpingi.

10 As the two aspects of legislative success are unlikely to be independent, a Heckman selection model can be used to model the adoption and amendment of government bills. Apart from the obvious theoretical connection, using a selection model is also important as changes to government legislation are only observed for bills that are eventually adopted by Alpingi. As it turns out, the estimated effects of our independent variable on how extensively bills are amended are hardly affected at all by whether we apply a Heckman model or a regular OLS regression.

11 A disadvantage of splitting the sample into pre- and post-crash periods is that it one cannot apply tests of statistical significance to compare the change in the coefficients. As will become clear, there is a quite sharp change in the patterns observed but to verify that the change in the coefficient was statistically significant we also ran models that interacted the key independent variables with a pre-/ post-crash dummy (which confirmed that the differences are statistically significant).

12 The sample of bills after the crisis is slightly smaller but it is unlikely that the lack of an effect here can be attributed to small sample size.

13 Comments made by other external actors did not have a statistically significant effect at the conventional level of statistical significance.

\section{References}

Andeweg, R.B., and Bakema W. (1994). "The Netherlands: Ministers and Aabinet Policy", in M. Laver and K.A. Shepsle (eds.), Cabinet Ministers and Parliamentary Government. (pp. 56-72). Cambridge: Cambridge University Press.

Bowler, S., Indridason, I.H., Bräuninger, T., and Debus, M. (2016). "Let's Just Agree to Disagree: Dispute Resolution Mechanisms in Coalition Agreements", The Journal of Politics 78(4), 1264-1278.

Bräuninger, T., and Debus, M. (2009). "Legislative Agenda-Setting in Parliamentary Democracies", European Journal of Political Research 48, 804-839.

Bäck, H., Müller, W., and Nyblade, B. (2017). "Multiparty Government and Economic Policy-Making. Coalition Agreements, Prime Ministerial Power and Spending in Western European Cabinets", Public Choice 170, 33-62.

Carroll, R., and Cox, G.W. (2012). "Shadowing Ministers: Monitoring Partners in Coalition Governments", Comparative Political Studies 45(2), 220-236.

Druckman, J., and Warwick P. (2005). "The Missing Piece: Measuring Portfolio Salience in Western European Parliamentary Democracies", European Journal of Political Research 44, 17-42.

Dunleavy, P., and Bastow, S. (2001). "Modelling Coalitions That Cannot Coalesce: A Critique of the Laver-Shepsle Approach", West European Politics 24(1), 1-26.

Eriksen, S. (2003). I Kongens Navn. Den Norske Regjeringen i Europeisk Perspektiv. Oslo: Statskonsult.

Kristinsson, G.H. (1996). "Parties, States and Patronage", West European Politics 19(3), 433-457.

Kristinsson, G.H. (2011). "Party Cohesion in the Icelandic Alpingi", Icelandic Revien of Politics and Administration 7(2), 229-251.

Kristinsson, G.H. (2016). "Specialists, Spinners and Networkers: Political Appointees in Iceland”, Acta Politica 51(4), 413-432. 
Indriðason, I.H. (2005). "A Theory of Coalitions and Clientelism: Coalition Politics in Iceland, 19452000", European Journal of Political Research 44(3), 439-464.

Indriðason, I.H., and Kristinsson, G.H. (2015). "Primary Consequences: The Effects of Candidate Selection Through Party Primaries in Iceland", Party Politics 21(4), 565-576.

Indriðason, I.H., and Kristinsson, G.H. (2013). "Making Words Count: Coalition Agreements and Cabinet Management", European Journal of Political Research 52(6), 822-846.

Laver, M., and Shepsle, K. (1994). "Cabinet Ministers and Government Formation in Parliamentary Democracies", in M. Laver and K. Shepsle (eds.), Cabinet Ministers and Parliamentary Government (pp. 3-15). Cambridge: Cambridge University Press.

Martin, L.W., and Vanberg, G. (2011). Parliaments and Coalitions. The Role of Legislative Institutions in Multiparty Governance. Oxford: Oxford University Press.

Moury, C. (2013). Coalition Government and Party Mandate: How Coalition Agreements Constrain Ministerial Action. Milton Park: Routledge.

Müller, W.C., and Strøm, K. (eds.) (2000). Coalition Governments in Western Europe. Oxford: Oxford University.

O’Malley, E. (2007). “The Power of Prime Ministers: Results of an Expert Survey”, International Political Science Review 28(1), 7-27.

Pedrazzani, A., and Zucchini, F. (2013). "Horses and Hippos: Why Italian Government Bills Change in the Legislative Arena, 1987-2006", European Journal of Political Research 52, 687-714.

Samhent stjórnsýsla (2010). Skýrsla nefndar um endurskodun laga um Stjórnarrád Íslands. Reykjavík: Prime Minister's Office.

SIC (Special Investigative Commission) (2010). Addragandi og orsakir falls íslensku bankanna 2008 og tengdir atburdir. Reykjavík: Alpingi.

Strøm, K., Müller, W.C., and Bergman, T. (eds.) (2003). Delegation and Accountability in Parliamentary Democracies. Oxford: Oxford University Press.

Thies, M. (2001). "Keeping Tabs of Partners: The Logic of Delegation in Coalition Governments", American Journal of Political Science 45(3), 580-598. 
166

\section{Appendix}

Figure A1. Summary statistics for change coefficient by legislative session

\begin{tabular}{crrccc}
\hline Legislative Session & Observations & Mean & Standard Deviation & Min & Max \\
\hline 130 & 105 & 17.67 & 25.39 & 0 & 96.16 \\
131 & 89 & 13.25 & 18.88 & 0 & 86.00 \\
132 & 112 & 14.69 & 20.48 & 0 & 85.39 \\
133 & 100 & 17.60 & 25.56 & 0 & 94.41 \\
134 & 7 & 14.33 & 13.46 & 0 & 33.43 \\
135 & 111 & 15.33 & 22.55 & 0 & 98.66 \\
136 & 76 & 19.17 & 26.09 & 0 & 98.71 \\
137 & 24 & 26.62 & 30.06 & 0 & 96.73 \\
138 & 113 & 16.19 & 20.98 & 0 & 96.85 \\
139 & 105 & 23.20 & 27.57 & 0 & 96.79 \\
140 & 71 & 22.54 & 23.28 & 0 & 94.06 \\
141 & 72 & 19.37 & 23.35 & 0 & 90.84 \\
142 & 10 & 31.63 & 35.69 & 0 & 87.44 \\
143 & 71 & 19.68 & 23.44 & 0 & 92.80 \\
\hline
\end{tabular}

